\title{
極超微粒子セメント注入材による砂質土地盤への注入工法の開発†

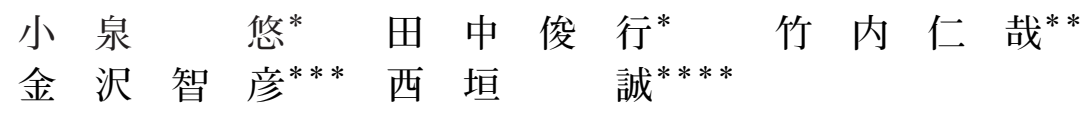 \\ Development of Grouting Method of Fine Sand with Ultrafine Cement Grout
}

\author{
by

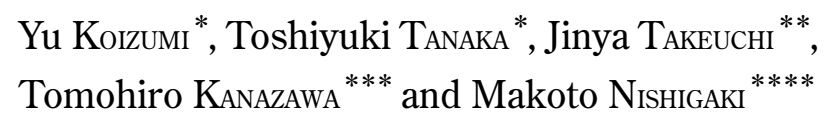

Grouting is an important part of construction in rock and soil for such as controlling the flow of water, filling voids in the ground and strengthening grounds. Grouting method has advantages over other soil improvement methods of not discharging slimes and requiring large spaces. However, conventional cement grout was difficult to permeate into fine sand. Chemical solution grout shows high permeability ; on the other hand, the solidified ground is not strong and durable enough. The purpose of our work is to develop grouting methods with ultrafine cement (the average particle size $1.5 \mu \mathrm{m}$ ) grout. The authors conducted both laboratory and field grouting tests. As a result, the grout permeated into a one-meter long artificial ground composed of fine sand, where conventional superfine cement grout was not able to permeate. Furthermore, unconfined compressive strength of the solidified ground was 10 times as large as that of solidified ground with chemical solution grout. As for the field test, the ball-shaped solidified ground was observed in the grouted area, and its diameter was $190 \mathrm{~cm}$ as designed. It is concluded from the tests that ultrafine cement grout showed a great permeability and high solidified strength.

Key words : Ultrafine cement, Grout, Grouting method, Permeability, Solidified strength, Lowered permeability coefficient

\section{1 緒言}

注入工法とは，ミキサーで練り混ぜた注入材を地盤の 間隙や岩盤のき裂等に注入充填して, 止水性や強度の増 加を図る地盤改良工法であり，土質地盤を対象とした地 盤注入と, 岩盤中のき裂を充填する岩盤注入に大別され る。このうち地盤注入は, 薬液を注入して, 地盤中の間 隙水を追い出し，充填・固化して地盤を改良するもので ある。従来, 薬液注入は, 耐久性に劣る水ガラス系材料 が用いられ，仮設工に使用されることが多かった。近年， 耐久性の高い薬液注入材が開発され, 而震補強や液状化 対策にも用いられているものの，Fig. 1 に示す水ガラス を主剤とする溶液型薬液注入材は, 浸透性に優孔るが改 良強度は小さい，また，セメント系固化材を主体とする 眯濁型薬液注入材は, 強度発現性に優れるものの, シル 卜分を含む細砂地盤への浸透は困難であるとされている. 一方, 岩盤注入は, 永久的で信頼性の高い止水を目的と する場合が多いため，Fig. 1 で極超微粒子注入材〜普通 セメントグラウトに示される強度と耐久性に優れたセメ ント系材料が用いられる。しかし，セメント系材料は， Fig. 1 に示すように, 粒径の大きさにより注入可能な地 盤が限定される。
そこで筆者らは，高い浸透性，高い強度発現性を有す る新しい注入材である “極超微粒子セメント注入材”に よる砂質土地盤への注入工法の開発を進めている.2) 4) 極 超微粒子注入材は, 従来のセメント系注入材よりもさら に粒径が小さいことから, 溶液型薬液注入材と同等の浸 透性を有し, 従来のセメント系注入材と同等の強度発現 性および耐久性を有するものと期待できる。また，本工 法は，高圧噴射摚拌工法等の地盤改良工法に比べて，ス ライム等の建設副産物の発生が無く, 環境負荷を低減す

\begin{tabular}{|c|c|c|c|c|c|c|}
\hline $\begin{array}{l}\text { Permeability coefficient } \\
\qquad(\mathrm{cm} / \mathrm{s})\end{array}$ & $10^{0}$ & $10^{-1} 10^{-2}$ & $10^{-3}$ & $10^{-4}$ & & \multirow{4}{*}{$\begin{array}{l}\text { Solidified } \\
\text { strength }\end{array}$} \\
\hline Particle size (mm) & \multicolumn{2}{|c|}{2.0} & & 75 & & \\
\hline$X^{2}$ & \multirow{2}{*}{ Gravel } & \multicolumn{2}{|c|}{ Sand } & \multirow{2}{*}{ Silt } & \multirow{2}{*}{ Clay } & \\
\hline Grout & & coarse & fine & & & \\
\hline Ultrafine cement grout & & & & & & High \\
\hline Superfine cement grout & & & $>$ & & & High \\
\hline Normal cement grout & & $P$ & & & & High \\
\hline Chemical suspension grout & & & $>$ & & & High \\
\hline Chemical solution grout & & & & $>$ & & Low \\
\hline
\end{tabular}

Fig. 1 Ground coverage of grouts ${ }^{1)}$ (retouched by authors). 
ることができる。ささに，施工設備が小規模であり，大 きなスペースが必要無いため，構造物が隣接し合う都市 現場の狭盆部での施工にも有効であると考えられる。

本論文では，はじめに極超微粒子注入材の材料特性に ついて述べる. 次に，室内 1 次元注入試験を実施し，極 超微粒子注入材の浸透性能を従来の注入材と比較した. そして, 室内 3 次元注入試験を実施することで，極超微 粒子注入材の改良効果を評価した。さらに，現場施工性 の検証を目的とした現場注入試験の結果を報告する.

\section{2 極超微粒子注入材の材料特性 ${ }^{2)}$}

極超微粒子注入材では，浸透性を向上させるために粒 径を小さくするとともに，粗大な水和物の生成を抑制す るため，主原料として高炉スラグを使用する。また，ポ リカルボン酸系分散郕を用い, 高速摚找することで凝集 粒子を分散させた. Fig. 2 に極超微粒子注入材と超微粒 子注入材の電子顕微鏡写真（5000 倍）を示すが，両者 の粒径の差異は明瞭である。Fig. 3 にレーザー散乱・回 折法により測定した極超微粒子注入材の粒度分布を示 す。罒中には，市販の超微粒子注入材，普通セメントの 粒度分布を併記した。極超微粒子注入材の平均粒径 $\left(D_{50}\right)$ は $1.5 \mu \mathrm{m}$ であり, 超微粒子注入材の $4 \mu \mathrm{m}$ に比べ て約 $1 / 3$ ，普通セメントの $20 \mu \mathrm{m}$ に比べて約 $1 / 13$ と極め て微細な材料である。

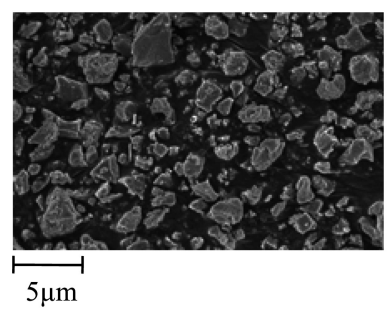

(a) Ultrafine cement

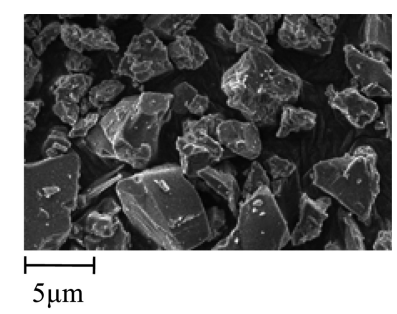

(b) Superfine cement
Fig. 2 Electron micrograph of cement.

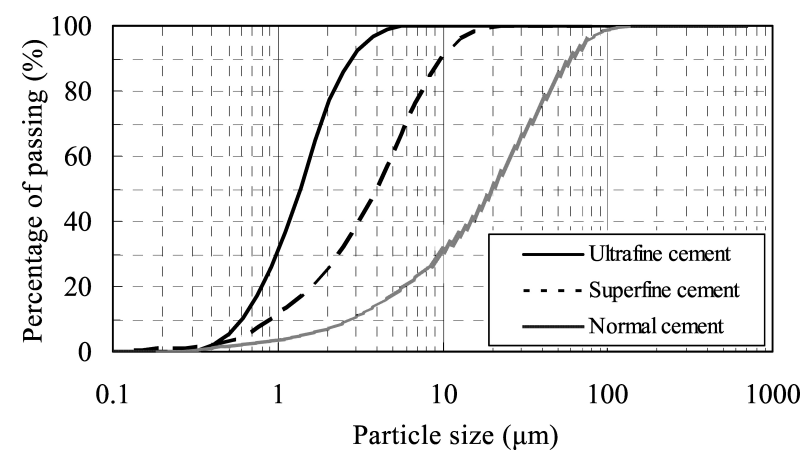

Fig. 3 Particle size distribution of cement.

\section{3 極超微粒子注入材の浸透性能の比較 ${ }^{3)}$}

極超微粒子注入材の浸透性能を評価するために，室内 1 次元注入試験を実施した。本章では，同一地盤に対す る極超微粒子注入材の浸透長を, 従来の注入材と比較し た結果について示す.

\section{$3 \cdot 1$ 試験方法}

室内 1 次元注入試験の概略図を Fig. 4 に示す。試験 地盤は，東北ケイ砂 7 号と 8 号を $1: 1$ で混合した試料 （細粒分含有率 $21 \%$ ）からなり，その物性を Table 1 に 示す，試験地盤は内径 $50 \mathrm{~mm}$ ，長さ $1025 \mathrm{~mm}$ のアクリル 円筒に, 所定の間隙率 $43 \%$ となるよう層厚 $25 \mathrm{~mm}$ ずつ試 料を投入し，ランマーを用いて突き固めることで作製し た。アクリル円筒の上下にフィルター層を $25 \mathrm{~mm}$ ずつ設 けて, 試験地盤の長さは $975 \mathrm{~mm}$ とした。極超微粒子注 入材の配合は, 水セメント比（以下W/C） 400\%，600\%, 800\%，1200\%，1600\%の 5 ケースとし，試験地盤を完全 に飽和させた後, 高速ミキサーで 3 分間攪拌して作液し たグラウトを試験地盤の限界圧力 $0.50 \mathrm{MPa}$ で筒底部より 注入した。また，比較のため市販の超微粒子注入材 $(\mathrm{W} / \mathrm{C}=800 \%)$ および懸濁型薬液注入材, 溶液型薬液注 入材についても同様に試験した。注入量は間隙体積に相 当する $823 \mathrm{~m} \ell$ とし, 上部から排出される間隙水量が注入 量に達したときに試験を終了した。注入より 7 日後，触 手により固化部分を確認し, 浸透長を測定した.

\section{$3 \cdot 2$ 試験結果}

各注入材の浸透長を Fig. 5 に示す．同罒に示されるよ うに, 従来の懸濁型薬液注入材は試験地盤に浸透せず, 超微粒子注入材でも約 $27 \mathrm{~cm}$ の浸透長しか得られなかっ た. 一方, 極超微粒子注入材 $\mathrm{W} / \mathrm{C}=400 \sim 800 \%$ のケー スでは, 設計通りの浸透長が得られ，溶液型注入材と同 等の高い浸透特性が示された。 W/C = 1200\% および $1600 \%$ のケースでは，浸透長はそれぞれ $81.3 \mathrm{~cm}, 50.5 \mathrm{~cm}$ と全長に達さなかった。

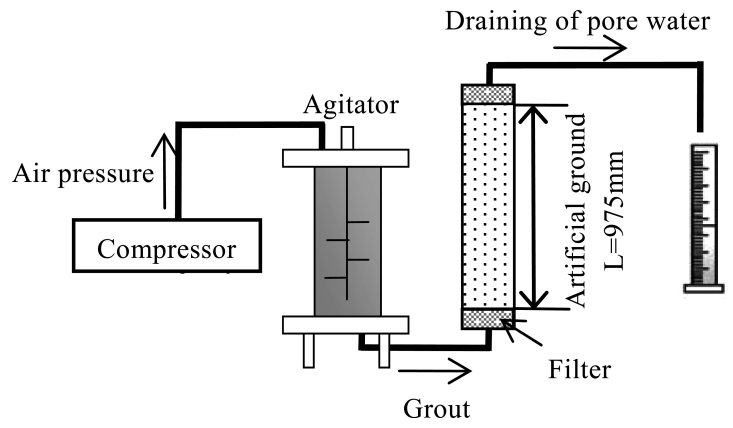

Fig. 4 Laboratory grouting test.

Table 1 Properties of artificial ground.

\begin{tabular}{c|c|c|c|c|c|c}
\hline \multicolumn{2}{c|}{ Material sand } & $\begin{array}{c}\text { Porosity } \\
(\%)\end{array}$ & $\begin{array}{c}\text { Content of fines } \\
(\%)\end{array}$ & $\begin{array}{c}\text { Relative density } \\
(\%)\end{array}$ & $\begin{array}{c}\text { Permeability coefficient } \\
(\mathrm{cm} / \mathrm{s})\end{array}$ & $\begin{array}{c}\text { Critical pressure } \\
(\mathrm{MPa})\end{array}$ \\
\hline \hline Silica sand & $\begin{array}{c}\text { Mixture of } \\
\# 7 \text { and \#8 (1:1) }\end{array}$ & 43 & 21 & 87 & $1.5 \sim 2.5 \times 10^{-3}$ & 0.50 \\
\hline
\end{tabular}




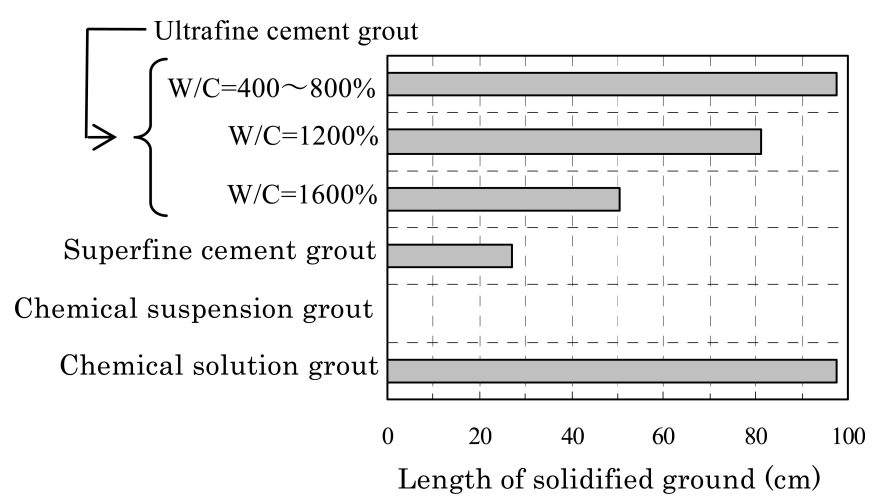

Fig. 5 Length of solidified ground of various grouts.

\section{4 室内 3 次元注入試験による改良効果の評価}

現場注入試験を実施するにあたり，その注入仕様を検 討するために，室内 3 次元注入試験を実施した。同試験 は, 室内 1 次元注入試験と現場注入試験の中間規模の試 験として位置付けられ，注入材の配合ごとに，改良体の 形状も含めた浸透特性の評価が可能である。 また，改良 体から採取したコアの一軸压縮強さや透水係数を求める ことで，改良効果を評価することができる，本章では， その試験方法打よび結果について示す.

\section{$4 \cdot 1$ 試験方法}

室内 3 次元注入試験の概要図を Fig. 6 に示す。試験 地盤は, 既述した室内 1 次元注入試験と同様に東北ケイ 砂 7 号と 8 号を $1: 1$ で混合した試料（細粒分含有率 $21 \%$ ) を用いて作製した。内径 $533 \mathrm{~mm}$, 高さ $690 \mathrm{~mm}$ のドラム 缶に, 層厚 $50 \mathrm{~mm}$ 分に相当する試料を順に投入し，ドラ ム缶の周囲を打撃し振動を与えながら水締めすることで, 間隙率を $43 \%$ に調整した。 ドラム缶の上下には粗砂から なるフィルター層を $50 \mathrm{~mm}$ ずつ設け，排水用の塩ビ管を 同層に上下各 2 本挿入した。極超微粒子注入材の配合は $\mathrm{W} / \mathrm{C}=400 \%, 600 \%, 800 \%, 1000 \%, 1200 \%, 1600 \%$ の 6 ケースとし，試験地盤を完全に飽和させて透水係数を求 めた後, 中央の注入管 $(\phi 20 \mathrm{~mm})$ より設計注入量 $12 \ell を$ 注入した。注入は流量一定条件で行い，注入速度は現場 相当の $8 \ell / \mathrm{min}$ とした。な打，設計注入量 $12 \ell$ 打よび間
隙率 $43 \%$ より，改良体の設計改良直径は $37.6 \mathrm{~cm}$ と算定 される。

注入の約 1 週間後, 試験地盤から改良体を掘り出し, $\mathrm{XYZ}$ 方向の改良径および重量を測定した。そして，コア サンプリングによる供試体（直径約 $43 \mathrm{~mm}$ ，高さ約 $86 \mathrm{~mm}$ ) を用いて，材齢 28 日で一軸圧縮試験および透水試験を 実施した。

\section{$4 \cdot 2$ 試験結果および考察}

試験条件打よび試験結果を Table 2 に示す。 また, 改 良体の形状を Fig. 7 に例示する。改良体の形状について は，極超微粒子注入材 $(\mathrm{W} / \mathrm{C}=800 \%)$ が設計通りの球状 となったのに対し，超微粒子注入材 $(\mathrm{W} / \mathrm{C}=800 \%)$ は扁 平で球形をなさなかった，そこで，改良体の大きさを同 一の指標で比較評価するために，式 (1) および式 (2)によ り, 改良体を球状と仮定したときの球相当直径を求め, Table 2 中に記載した。また, 設計改良直径 $37.6 \mathrm{~cm}$ に 対する球相当直径の割合を改良率と定義し，試験ケース ごとの改良率を算出した。

$$
\begin{aligned}
& \rho_{\text {impr. }}=\rho_{s} \times(1-n)+\rho_{g} \times n \\
& r_{\text {equiv. }}=\sqrt[3]{\left(\frac{3}{4 \pi} \cdot \frac{W}{\rho_{\text {impr. }}}\right)}
\end{aligned}
$$

ここで, $\rho_{\mathrm{s}}$ : 地盤の土粒子密度 $\left(\mathrm{g} / \mathrm{cm}^{3}\right), \rho_{\mathrm{g}}$ : グラウ 卜密度 $\left(\mathrm{g} / \mathrm{cm}^{3}\right), \rho_{\text {impr. }}$ : 改良体の湿潤密度 $\left(\mathrm{g} / \mathrm{cm}^{3}\right)$, $n$ : 間隙率 $(\%), r_{\mathrm{equiv}}$ : 球相当直径 $(\mathrm{cm}), W$ : 改良体の 質量 $(\mathrm{g})$ である.

$\mathbf{4} \cdot \mathbf{2} \cdot 1$ 改良率 各試験ケースの改良率と $\mathrm{W} / \mathrm{C}$ の関 係を Fig. 8 に示す. 極超微粒子注入材で, W/C の増加, すなわちセメント量の減少に伴い改良率が低下する関係 が認められた. W/C = 400\%～800\% の改良率が約 90\% 以上であるのに対し, $\mathrm{W} / \mathrm{C}=1000 \%$ は $83.0 \%, \mathrm{~W} / \mathrm{C}=$ $1200 \%$ は $80.7 \%$ となり, 室内 1 次元注入試験結果と同様 に, W/C = 800\% 1200\%で改良率が顕著に低下する傾 向が認められた，次に，超微粒子注入材であるが，設計 注入量 $12 \ell$ を全量注入できたものの，改良体の形状は扁 平で球形をなさず，改良率は約 $60 \%$ と小さかった。

以上, 室内 3 次元注入試験を実施した結果，極超微粒

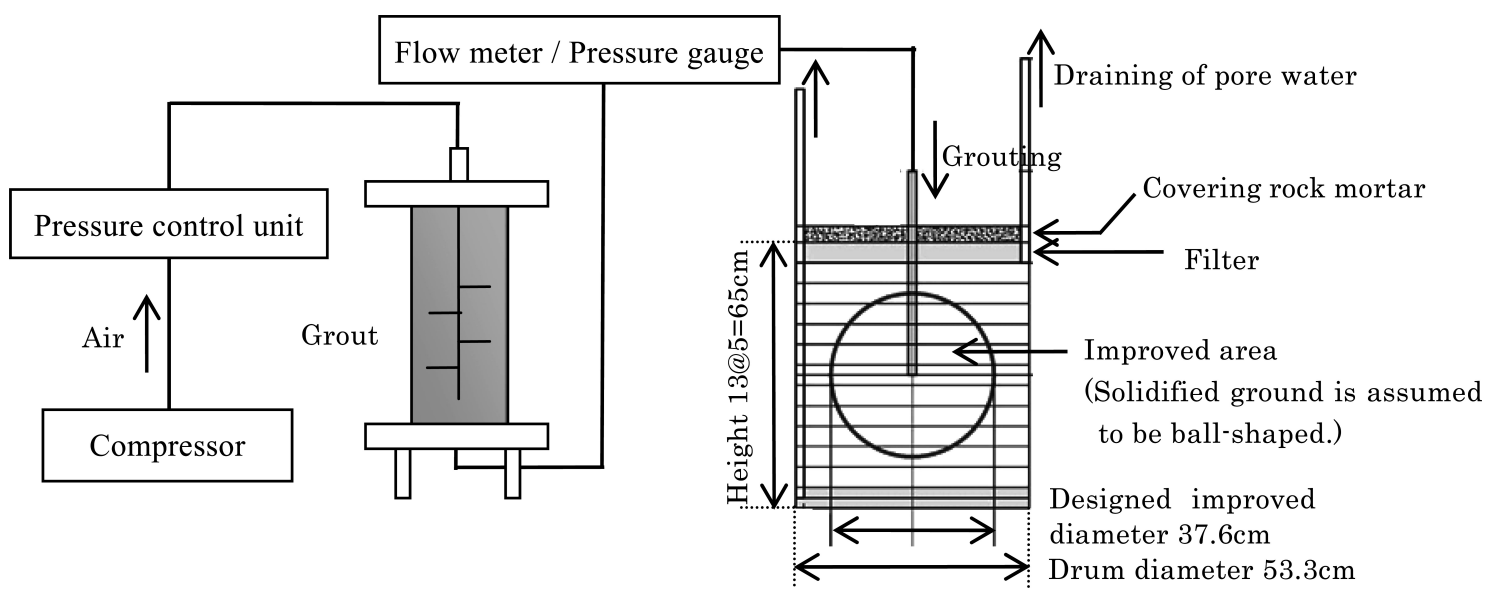

Fig. 6 Laboratory grouting test (three-dimensional). 


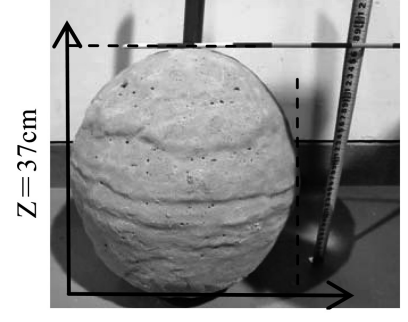

$\mathrm{X}=34 \mathrm{~cm}$

(a) Ultrafine cement grout $(\mathrm{W} / \mathrm{C}=800 \%)$

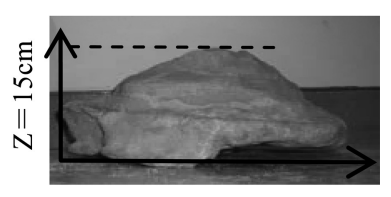

$\mathrm{X}=40 \mathrm{~cm}$

(b) Superfine cement grout $(\mathrm{W} / \mathrm{C}=800 \%)$
Fig. 7 Shape of solidified ground.

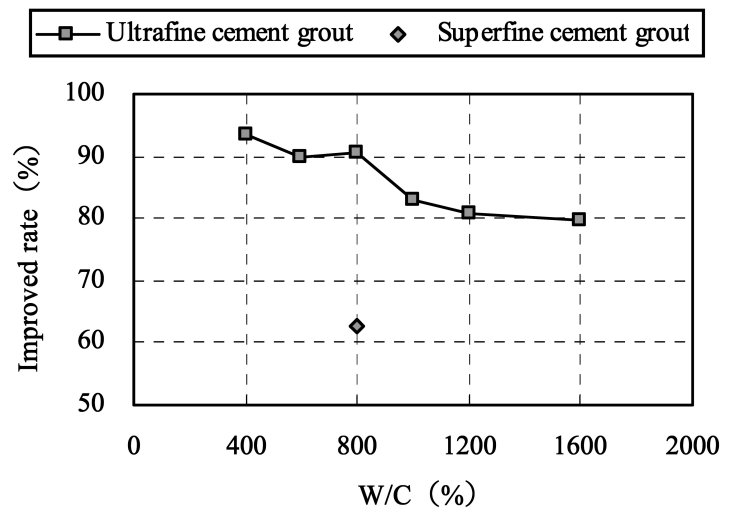

Fig. 8 Relationship between improved rate and W/C.

子注入材の改良率は約 $90 \%$ が得られており，その形状は 設計通りの球状であった。従来の超微粒子注入材に比較 して，極超微粒子注入材の高い浸透特性が示された。

$4 \cdot 2 \cdot 2$ 改良強度 極超微粒子注入材 $(\mathrm{W} / \mathrm{C}=400 \%$ 1600\%)の改良体から得た供試体の一軸圧縮試験結果 o28 を Fig. 9 に示す. 同図の横軸である注入管からの離 隔とは，注入管からコアの中心までの距離を示す． Fig. 9 から，一軸圧縮強さは注入孔からの離隔にほとんど依存 せず，各試験ケースでほぼ一定の值を取ることが分かる. つまり，注入材は均質に浸透し，全体的に改良されたも のと考えられる. Table 2 に示す極超微粒子注入材の改 良強度を, 文献 ${ }^{5}$ に基づく一般的な溶液型薬液注入材の 改良強度 $250 \mathrm{kN} / \mathrm{m}^{2}$ と比較すると, $\mathrm{W} / \mathrm{C}=400 \%$ で溶液
型薬液注入材の約 30 倍, $\mathrm{W} / \mathrm{C}=600 \%, 1000 \%$ で約 16 倍, $\mathrm{W} / \mathrm{C}=800 \%, 1200 \%$ で約 10 倍の高い改良強度が示 された。なお， $\mathrm{W} / \mathrm{C}=800 \%$ の改良強度は $\mathrm{W} / \mathrm{C}=1000 \%$ の改良強度を下回った。これは $\mathrm{W} / \mathrm{C}=800 \%$ の改良率が $90.6 \%$ と高く，W/C = 800\%の改良体は，体積に換算し て $\mathrm{W} / \mathrm{C}=1000 \%$ の 1.3 倍あることから，改良体の単位 体積当たりのセメント量が $\mathrm{W} / \mathrm{C}=1000 \%$ よりも小さく なったためと考えられる。ただし，W/C = 800\% の改良 強度 (約 $\left.2500 \mathrm{kN} / \mathrm{m}^{2}\right)$ でも, 液状化はもとより地盤強化 が目的とされる場合にも通常十分な改良強度が破保され ている。本試験結果において，W/C = 800\%のケースは， $\mathrm{W} / \mathrm{C}$ が中程度であるのに対して改良率が 2 番目に高いこ とから，グラウトの材料単価および注入工事の数量が低 減可能となる最も経済的な配合であると考えられる.

$4 \cdot 2 \cdot 3$ 改良透水係数 改良透水係数も, 一軸圧縮 強さと同様に，注入中心からの離隔にほとんど依存せず， Table 2 に示すような結果となった。試験地盤の透水係 数と比較すると, 注入後, 極超微粒子注入材 $\mathrm{W} / \mathrm{C}=$ 400\%，600\%，1000\%で 3 オーダー，穴の他の W/C で 2 オーダー透水係数が低下した。 また, 原位置地盤の透水性 を表す指標であるルジオン值に換算すると $(1 \mathrm{Lu} \fallingdotseq 1.3 \times$

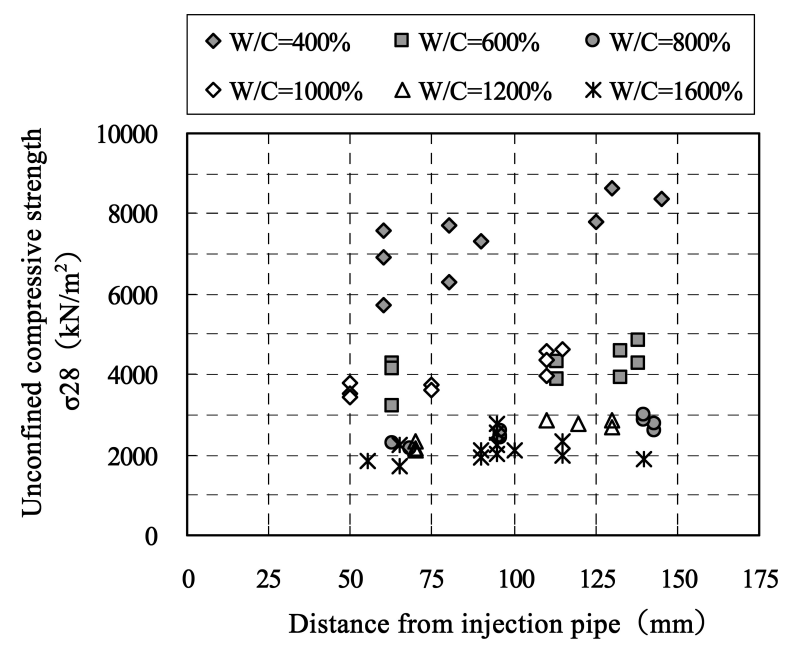

Fig. 9 Relationship between unconfined compressive strength and distance from injection pipe.

Table 2 Conditions and results of experiments.

\begin{tabular}{|c|c|c|c|c|c|c|c|c|c|c|c|c|c|}
\hline \multicolumn{2}{|c|}{ Grout } & \multicolumn{2}{|c|}{ Ground properties } & \multicolumn{6}{|c|}{ Size and weight of solidified ground } & \multicolumn{4}{|c|}{ Properties of solidified ground } \\
\hline \multirow[t]{2}{*}{ Material } & \multirow{2}{*}{$\begin{array}{l}\mathrm{W} / \mathrm{C} \\
(\%)\end{array}$} & \multirow{2}{*}{$\begin{array}{c}\text { Material and } \\
\text { porosity }\end{array}$} & \multirow{2}{*}{$\begin{array}{c}\text { Permeability } \\
\text { coefficient } \\
(\mathrm{cm} / \mathrm{s})\end{array}$} & \multicolumn{3}{|c|}{ Length $(\mathrm{cm})$} & \multirow{2}{*}{$\begin{array}{c}\text { Equiavalent } \\
\text { diameter } \\
(\mathrm{cm})\end{array}$} & \multirow{2}{*}{$\begin{array}{c}\text { Improved } \\
\text { rate } \\
(\%)\end{array}$} & \multirow{2}{*}{$\begin{array}{c}\text { Weight } \\
(\mathrm{kg})\end{array}$} & \multicolumn{2}{|c|}{$\begin{array}{c}\text { Unconfined compressive } \\
\text { strength }\left(\mathrm{kN} / \mathrm{m}^{2}\right)\end{array}$} & \multicolumn{2}{|c|}{ Permeability coefficient $(\mathrm{cm} / \mathrm{s})$} \\
\hline & & & & $\mathrm{X}$ & $\mathrm{Y}$ & $\mathrm{Z}$ & & & & Range & Ave. & Range & Ave. \\
\hline \multirow{6}{*}{$\begin{array}{l}\text { Ultrafine } \\
\text { cement }\end{array}$} & 400 & \multirow{7}{*}{$\begin{array}{c}\text { Silica sand } \\
\# 7(50) \\
\text { and } \\
\# 8(50)\end{array}$} & \multirow{7}{*}{$\begin{array}{l}2.0 \sim 4.0 \\
\times 10^{-3}\end{array}$} & 34.0 & 34.0 & 35.0 & 35.1 & 93.4 & 45.4 & $5700 \sim 8600$ & 7370 & $5.5 \times 10^{-7} \sim 1.1 \times 10^{-6}$ & $7.3 \times 10^{-7}$ \\
\hline & 600 & & & 34.0 & 35.0 & 35.0 & 33.8 & 89.8 & 40.0 & $3800 \sim 4800$ & 4180 & $2.8 \sim 6.5 \times 10^{-6}$ & $4.3 \times 10^{-6}$ \\
\hline & 800 & & & 34.0 & 33.5 & 37.0 & 34.1 & 90.6 & 40.8 & $2200 \sim 3000$ & 2580 & $2.4 \sim 4.0 \times 10^{-5}$ & $3.1 \times 10^{-5}$ \\
\hline & 1000 & & & 29.5 & 29.5 & 31.5 & 31.2 & 83.0 & 31.2 & $3400 \sim 4600$ & 4000 & $3.4 \sim 5.6 \times 10^{-6}$ & $4.4 \times 10^{-6}$ \\
\hline & 1200 & & & 30.0 & 30.0 & 30.5 & 30.3 & 80.7 & 28.6 & $2100 \sim 2900$ & 2550 & $3.9 \sim 4.1 \times 10^{-5}$ & $3.9 \times 10^{-5}$ \\
\hline & 1600 & & & 27.5 & 27.0 & 34.0 & 30.0 & 79.8 & 27.6 & $1700 \sim 2800$ & 2140 & $2.5 \sim 3.3 \times 10^{-5}$ & $2.8 \times 10^{-5}$ \\
\hline $\begin{array}{c}\text { Superfine } \\
\text { cement }\end{array}$ & 800 & & & 40.0 & 39.0 & 15.0 & 23.6 & 62.7 & 13.5 & - & - & - & - \\
\hline
\end{tabular}


$\left.10^{-5} \mathrm{~cm} / \mathrm{s}\right), \mathrm{W} / \mathrm{C}=400 \%, 600 \%, 1000 \%$ でルジオン值 $1 \mathrm{Lu}$ を下回り，ダム基礎地盤の一般的な改良目標值 $2 \mathrm{Lu}^{6)}$ を満たす高い止水性が示された。

\section{5 現場注入試験による施工性の検証 ${ }^{4)}$}

室内 1 次元注入試験および 3 次元注入試験の実施結果 を踏まえ, 本注入工法の施工性を検証するために, 砂質 土を対象とした極超微粒子注入材の現場注入試験を実施 した。本章では，その試験方法扎よび結果について示す。

\section{$5 \cdot 1$ 地盤条件}

現場注入試験は千葉県富津市で実施した。事前の地盤 調査の結果から, GL-2.0m までは埋戻土 (粘性土)で，そ の下部に地下水位 GL-1.5m 以下の注入対象となる砂質土 が分布することを確認した。砂質土は砂州性堆積物であ り, $\mathrm{N}$ 值 $17 \sim 27$ の砂混じり中砂〜細砂からなる. 細粒 分含有率は $2 \sim 3 \%$ で，室内 3 次元注入実験で注入対象 地盤としたケイ砂 7 号と 8 号の混合砂（混合比 $1: 1$ ）よ りも粒径が粗かった。一方で間隙率は $36 \%$ と小さく, 相対 密度は $100 \%$ 以上, 透水係数は $4.7 \times 10^{-3} \mathrm{~cm} / \mathrm{s}$ であった。

\section{$5 \cdot 2$ 注入方法}

極超微粒子注入材の配合は，W/C $=400 \%, 800 \%$, $1200 \%$ の 3 配合とし，注入速度は $15 \ell / \mathrm{min}$ とした。設 計改良直径 $\phi 2.0 \mathrm{~m}$ の球体を想定し，充填率を $125 \%$ と設 定して，次式により注入量を算出した。

$Q=V \times n \times \alpha=\left(\frac{4 \times \pi \times 1.0^{3}}{3}\right) \times 0.36 \times 1.25=1880(\ell)(3)$ ここで, $Q$ : 注入量 $(\ell), V$ : 改良体体積 $\left(\mathrm{m}^{3}\right), n$ : 対象 地盤の間隙率 $(\%), \alpha:$ 充填率 $(\%)$ である.

注入方法の概略図を Fig. 10 に示す. 削孔径 $90 \mathrm{~mm}$ で ボーリングを行い，孔内に注入区間長として $\mathrm{L}=1.0 \mathrm{~m}$ のストレーナ加工した $\phi 40 \mathrm{~mm}$ 塩化ビニル製パイプ（注 入パイプ）を設置した。注入パイプには $\mathrm{L}=1.0 \mathrm{~m}$ の布 製パッカーを注入区間の上部に取り付け，地表部への注 入材漏出防止とした。

練混ぜは，水 $\rightarrow$ (分散剂 + 消泡剂 $) \rightarrow$ 極超微粒子注 入材料の順でミキサーに投入し，3 分間高速攪挥を行っ た。注入は，所定の速度で定量注入し，注入量が計画注 入量に達した時点で注入完了とした。流量と圧力は循環 式流量計で測定し，データ処理装置で収録した。

\section{$5 \cdot 3$ 試験結果}

$5 \cdot 3 \cdot 1$ 有効注入圧力 各試験ケースとも計画量を注 入でき，地表部へのリークは無かった，有効注入圧力は 時間の経過とともに上昇し，W/C が小さい富配合のケー スほど有効注入圧力は高くなった。なお，最大有効注入 圧力は $\mathrm{W} / \mathrm{C}=400 \%$ で $0.52 \mathrm{MPa}$ であった。

$5 \cdot 3 \cdot 2$ 改良強度, 透水係数および $\mathbf{S}$ 波速度 注入孔 からそれぞれ $0.25 \mathrm{~m} ， 0.50 \mathrm{~m} ， 0.75 \mathrm{~m}$ 離れた位置でチェッ クボーリングを行い，改良コアを採取，成形して材齢 28 日で一軸圧縮強度試験に供した。室内 3 次元注入試験と 同様に, 改良体の内部 $(0.25 \mathrm{~m})$ と側部 $(0.5 \mathrm{~m}$ または $0.75 \mathrm{~m}$ ）で大きな強度差は無く，改良体が均質に形成さ れていることが確認できた，W/C = 400\%の改良強度は $7000 \mathrm{kN} / \mathrm{m}^{2}$ 以上と高強度で，またその他の配合でも $3000 \mathrm{kN} / \mathrm{m}^{2}$ 以上の強度を有し, 室内試験結果とよく整合 した.

改良後のコアの透水係数は，W/C $=400 \%$ で $1 \times 10^{-8}$ 〜 $1 \times 10^{-6} \mathrm{~cm} / \mathrm{s}, \mathrm{W} / \mathrm{C}=800 \%$ で $1 \times 10^{-6} \sim 1 \times 10^{-5} \mathrm{~cm} / \mathrm{s}$ の高い止水性が得られており，原地盤と比較して透水係 数を 2 〜オーダー低減できた。

$5 \cdot 3 \cdot 3$ 改良出来形 注入完了後，約 1 ヶ月の養生 期間を経て地盤を掘削し，改良体の出来形を確認した. 掘削は改良体の頭部付近まで行い，改良体頭部の出来形 を計測した. Fig. 11 に $/ \mathrm{C}=400 \%$ の改良体出来形を例 示する。いずれも注入材の割裂脈は無く球状を呈してお り，土粒子間を均質に浸透注入できたことが確認された。 また，頭部改良径 $\phi$ は，W/C $=400 \%$ で $\phi 1.9 \sim 2.0 \mathrm{~m}$, $\mathrm{W} / \mathrm{C}=800 \%$ で $\phi 1.8 \sim 1.9 \mathrm{~m}, \mathrm{~W} / \mathrm{C}=1200 \%$ で $\phi 1.5 \sim$ $1.6 \mathrm{~m}$ であった。室内試験の結果と同様に W/C が小さい ほど改良径は大きく，W/C = 400\%，800\%のケースで概 ね計画通りの出来形を得ることができた。

\section{6 結}

言

得られた知見を以下に示す

(1) 室内 1 次元注入試験を実施し，細粒分含有率 $21 \%$, 透水係数 $1.5 \sim 2.5 \times 10^{-3} \mathrm{~cm} / \mathrm{s}$ の試験地盤に対する極超 微粒子注入材の浸透性能を従来の注入材と比較した。そ の結果，超微粒子注入材および奬濁型薬液注入材が目詰

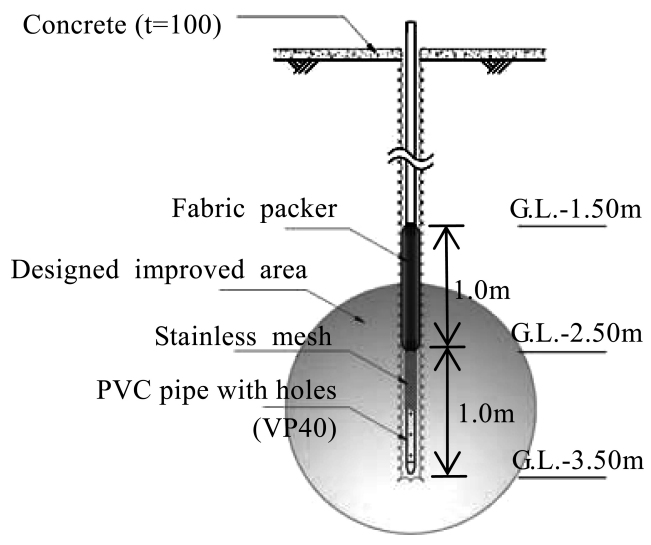

Fig. 10 Grouting method

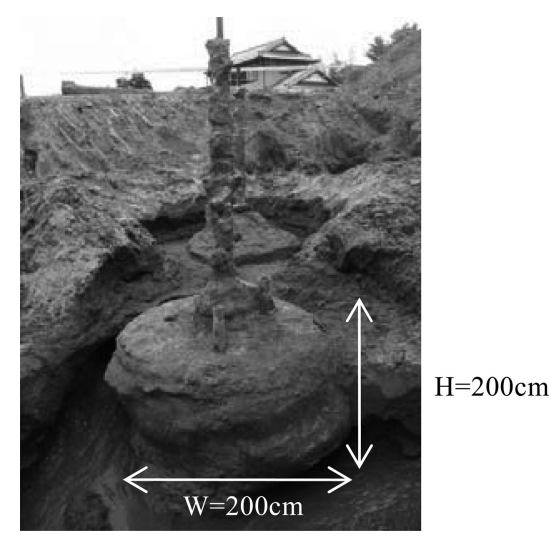

Fig. 11 Observed solidified ground $(\mathrm{W} / \mathrm{C}=400 \%, Q=15 \ell / \mathrm{min})$. 
まりした地盤に対し，極超微粒子注入材（W/C = 800\% 以下）は，溶液型薬液注入材と同様に設計改良長が得ら れ，高い浸透性能が示された。

(2) 室内 3 次元注入試験を実施し, 細粒分含有率 $21 \%$, 透水係数 $2.0 \sim 4.0 \times 10^{-3} \mathrm{~cm} / \mathrm{s}$ の試験地盤に対する極超 微粒子注入材の 3 次元的な浸透特性および改良効果を調 査した。その結果，超微粒子注入材では改良体の形状が 扁平となったのに対し, 極超微粒子注入材では球状の改 良体が得られた。 $\mathrm{W} / \mathrm{C}=400$ ～800\% での改良率は概ね $90 \%$ 以上で，W/C = $1200 \%$ では約 $80 \%$ であった．改良 体の材齢 28 日の一軸圧縮強さは $\mathrm{W} / \mathrm{C}=400 \%$ で $7000 \mathrm{kN} / \mathrm{m}^{2}$ 程度, $\mathrm{W} / \mathrm{C}=800 \%$ で $2500 \mathrm{kN} / \mathrm{m}^{2}$ 程度あり, 溶液型薬液注入材と比較して 10 倍以上の高い改良強度 が示された. また, 改良体の透水係数は W/C = 400\%で $10^{-7} \mathrm{~cm} / \mathrm{s}$ オーダー, W/C $=600 \%, 1000 \%$ で $10^{-6} \mathrm{~cm} / \mathrm{s}$ オー ダー, W/C $=800 \%, 1200 \%$ で $10^{-5} \mathrm{~cm} / \mathrm{s}$ オーダーが得ら れた.

（3）現場注入試験を実施し，本注入工法の施工性を 検証した。そ結果, 細粒分含有率 $2 \sim 3 \%$ のよく締まっ た砂地盤に対し，注入速度 $15 \mathrm{l} / \mathrm{min}$ で良好に注入する ことができた．改良体の一軸圧縮強さは $\mathrm{W} / \mathrm{C}=400 \%$ で $7000 \mathrm{kN} / \mathrm{m}^{2}$ 程度, $\mathrm{W} / \mathrm{C}=800 \%, 1200 \%$ でも $3000 \mathrm{kN} / \mathrm{m}^{2}$ 以上と高強度で， $\mathrm{W} / \mathrm{C}=400 \%, 800 \%$ のケースでほぼ設 計通りの球状改良体が確認できた。

以上，本注入工法は細砂地盤に対して十分な浸透性を 有し，地盤を高強度に改良することができる。また，設 備は比較的小規模で済み, 都市現場の狭险部での施工に も適用可能である。このような地盤改良効果と注入工法 の特長により，大型の土木構造物のみならず，住宅や災
害発生時に避難所となる学校等重要施設の液状化防止や 耐震補強にも有効である。今後は地盤条件に応じた最適 な注入の設計施工法について更なる検討を進めるととも に，現場での施工実績を積み上げられるよう努力してい く所存である.

\section{参考文 献}

1) R. Yonekura, S. Shimada and Y. Kinoshita, "Permanent grout”, p.130 (2000) Sankaido.

2 ) T. Kanazawa, S. Wakasugi, M. Nishigaki, T. Yamamoto and Y. Abe, "Development of grouting method with ultra fine cement grout -Material characteristics-”, Proceedings of the 65th JSCE 2010 Annual Conference, CD-ROM, III-479, pp.957-958 (2010) JSCE.

3 ) Y. Koizumi, T. Tanaka, M. Nishigaki, J. Takeuchi and T. Kanazawa, "Development of grouting method with ultra fine cement grout -Laboratory grouting test-”, Proceedings of the 65th JSCE 2010 Annual Conference, CD-ROM, III-480, pp.959-960 (2010) JSCE.

4 ) J. Takeuchi, T. Hamago, M. Nishigaki, T. Tanaka, Y. Koizumi and T. Kanazawa, "Development of grouting method with ultrafine cement grout -Field grouting test-”, Proceedings of the 65th JSCE 2010 Annual Conference, CD-ROM, III-481, pp.961-962 (2010) JSCE.

5 ) R. Yonekura and S. Shimada, "Characteristics of permanent grout”, Journal of Civil Engineering, Vol.40, No.8, pp.104-109 (1999).

6) Japan Institute of Construction Engineering, "Grouting technical guide”, pp.32-35 (2003) Taisei shuppan. 